\title{
(NE)ZÁVISLOSŤ NA POLI: KOGNITÍVNY ŠTÝL ČI SCHOPNOSŤ?
}

\author{
LENKA KRAJČÍKOVÁ \\ Psychologický ústav, Filozofická fakulta Masarykovy univerzity ${ }^{1}$
}

\begin{abstract}
Abstrakt: Predkladaný krátky článok pojednáva o testovaní kognitívneho štýlu závislosti/nezávislosti na poli podl'a Witkina. Tento kognitívny štýl popísaný v 50. rokoch bol v niekol'kých posledných dekádach vystavený kritike, ktorá sa na jednej strane týka samotnej definície kognitívneho štýlu, na strane druhej i metód, ktoré sú k testovaniu tohto štýlu používané. V práci sa čitatel' dozvie ako o metódach testovania závislosti/nezávislosti na poli tak o kritike tohto konceptu. Hlavným zámerom článku je poskytnút' historický exkurz do testovania kognitívneho štýlu závislosti/nezávislosti na poli pomocou testu $k$ tomu pôvodne určenému (Embedded Figures Test). Čitatel' sa dozvie o nejednoznačnosti použitia testu EFT a pochybnostiach o tom, že skutočne testuje spomínaný kognitívny štýl. Test samotný bude predstavený $v$ novom svetle potenciálne zaujímavého nástoja na testovanie priestorovej kognitívnej schopnosti či všeobecnej inteligencie, čo je však nutné d'alším výskumom objasnit'.
\end{abstract}

Klíčová slova: závislost' na poli, kognitívny štýl, kognitívna schopnost', psychometrika

\section{Úvod}

Prvé zmienky o koncepte psychologickej diferenciácie v zmysle kognitívnych štýlov sa datujú už do pät'desiatych rokov dvadsiateho storočia, kedy Witkin predstavil svoj pohl'ad na kognitívne štýly spolu so samotným štýlom závislosti a nezávislosti na poli (Witkin, 1950, 1979). Všeobecnú definíciu kognitívnych štýlov poskytuje Goodenoughová:

„Kognitívne štýly boli definované ako individuálne rozdiely zahrňujúce spôsob kognitívneho fungovania, ktorý sa odráža v širokej škále oblastí, od intelektuálnej cez sociálnu a interpersonálnu až po osobnostne obranné mechanizmy" (vol'ne preložené z Goodenough, 1976, p. 1).

Kognitívne štýly teda môžeme chápat', ako interindividuálne rozdiely v kognitívnom spracovaní informácii, akési kognitívne stratégie, pri spracovaní informácií, ktorých využitie vedie k rôznym výsledkom vo vnímaní sveta okolo (Kozhevnikov, 2007).

\footnotetext{
${ }^{1}$ Psychologický ústav, Filozofická fakulta Masarykovy univerzity, Arna Nováka 1/1, 60200 Brno. Doručeno do redakce: 16 . květen 2017.
} 
Witkinov koncepte závislosti a nezávislosti na poli je teda jedným z mnohých kognitívnych štýlov (Kozhevnikov, 2007). Predstavuje dichotomický štýl, ktorý rozdel’uje l'udí na základe spôsobu spracovania informácii z okolia (pole). Pole vo Witkinovom pojatí chápeme ako kognitívne pole, z ktorého prichádzajú informácie. Pole teda predstavuje zdroj informácií, ktoré sú jednotlivcom spracovávané (Poirel et al., 2008; Witkin, 1965; Witkin et al., 1979).

Samotný štýl hovorí o dvoch skupinách l'udí, teda jedincoch závislých a nezávislých na poli. Závislost' na poli sa prejavuje globálnym spracovaním informácií, čo môžeme chápat' ako spracovanie informácií bez ohl'adu na kontext, akúsi neschopnost' vnímat' objekty nezávisle na ich okolí (Čeněk, 2016)². Pole, teda zdroj informácií, je vnímané ako dané, jednotlivci závislí na poli majú t’ažkosti s oddelením figúry od pozadia, sú náchylní ku zákonom Gestaltu (ako napríklad zákon dobrého tvaru, zákon blízkosti, zákon spoločného osudu a pod.; Wagemans et al., 2012). Spracovanie informácií je menej diferencované. Zatial' čo jedinci nezávislí na poli dokážu s informačným pol’om pracovat', oddelit' jednoducho figúru od pozadia a efektívne využívat' tie informácie, ktoré v danej chvíli potrebujú, zároveň nepotrebné informácie zatlačit’ do pozadia. Predstavujú systém spracovania podnetov z okolia, ktorý je omnoho viac diferencovaný, ako u predošlej skupiny (Witkin, 1965; Witkin et al., 1979).

\section{Psychometrické zhodnotenie metód používaných na meranie závislosti/nezávislosti na poli}

V nasledujúcej sekcii budú vkrátkosti popísané metódy testovania závislosti a nezávislosti na poli, ich porovnanie, hlavný dôraz ale bude na EFT (Embedded Figures Test), jeho normy a použitie.

\section{Testovanie závislosti a nezávislosti na poli}

V nasledujúcej kapitole budú predstavené metódy používané na testovanie závislosti a nezávislosti na poli. Všetky d’alej spomenuté metódy majú korene v pôvodnej Witkinovej práci a boli navrhnuté autorom a jeho kolegami. Typickým príkladom úloh využívaných pri testovaní závislosti a nezávislosti na poli sú úlohy, kde je participant inštruovaný operovat' s figúrou a pozadím oddelene. Tento typ úlohy predstavuje test RFT (Rod-and-Frame), kde testovaná osoba sedí v zatemnenej miestnosti a pozoruje štvorec, ktorého okraje svietia rovnako ako tyč umiestnená v štvorci. Štvorec je nachýlený o $28^{\circ}$ od zvislej osi. Úlohou participanta je dial'kovým ovládaním nastavit' tyč do zvislej polohy nezávisle od štvorca v 24 po sebe nasledujúcich pokusoch (Svoboda, 2010). Ako už bolo povedané vyššie, jednotlivci závislí na poli majú problémy oddelit' figúru od pozadia, v RFT dosahujú signifikantne horšie výsledky ako jedinci nezávislí na poli. Podobné výsledky boli dosiahnuté aj v BAT (Body Adjustment Test), kde je participant umiestnený do zatemnenej miestnosti na naklonené kreslo, ktoré má opät' dial'kovým

\footnotetext{
2 Jiř́i Čeněk sa vo svojej práci zaoberá kognitívnymi štýlmi a kultúrou. Pre detailnejšie informácie,
} metodológiu a výsledky odporúčam jeho dizertačnú prácu. 
ovládaním dostat' do zvislej polohy. Alternatívu predstavuje RRT (Rotating-Room Test), kde participant pohybuje naopak s miestnost'ou samotnou tak, aby našiel zvislú polohu miestnosti odhliadnuc od kresla, v ktorom sedí (Witkin, 1965; Witkin et al., 1979).

Testy popísané vyššie sú už na prvý pohl'ad náročné na realizáciu, zároveň je vždy nutná individuálna administrácia. Preto bol Witkinom vytvorený test v papierovej podobe, ktorý je možné administrovat' hromadne ako i jednotlivo. Jedná sa o (G)EFT ((Group) Embedded Figures Test; Witkin, 1950), ktorého podstatou je v 24 úlohách lokalizovat' jednoduchú figúru $\mathrm{v}$ komplexnom dizajne. Úlohy boli $\mathrm{v}$ originálnom zadaní administrované jednotlivo každému participantovi zvlášt', a to v poradí komplexný dizajn po dobu 15 sekúnd, následne figúra po dobu 10 sekúnd a nakoniec opät' komplexný dizajn, kde bol participant inštruovaný nájst' jednoduchú figúru. Test obsahoval čierno-biele ako aj farebné úlohy. Pri administrácí úloh sa participant mohol vrátit' $\mathrm{k}$ jednoduchému tvaru, ale komplexný dizajn bol v tom prípade skrytý. Participant tak nikdy nevidel oba obrázky zároveň. Ak sa participantovi nepodarilo lokalizovat' jednoduchú figúru vkomplexnom dizajne do 5 minút, úloha bola považovaná za nesplnenú. Pri testovaní sa sledoval počet správnych odpovedí a celkový čas na splnenie všetkých 24 úloh.

Navrhnutá bola i skrátená forma EFT a to 12položková varianta, ktorá dostatočne diskriminovala medzi extrémnymi skupinami participantov závislých a nezávislých na poli a zároveň silne korelovala $(\mathrm{r}=$.99) s kompletným 24 položkovým testom (Jackson, 1956).

\section{Normy a psychometrické vlastnosti GEFT}

Normy boli pôvodne vytvorené na 120 pregraduálnych študentoch, z ktorých 60 bolo mužov. Normy boli vytvorené pre mužov a ženy zvlášt', ked'že sa zistilo, že ženám trvá vyriešenie úloh signifikantne dlhšie ako mužom, Witkin teda predpokladá, že ženy sú častejšie závislé na poli ako muži, ktorí vykazujú vyššiu nezávislost' na poli (Witkin, 1950). Tento záver bol jedných z dôvodov, prečo bolo nutné normy revalidizovat'. Pôvodné normy boli tiež vytvorené na skupine študentov, preto bolo žiaduce zistit', či budú rovnako platné i na dospelú populáciu.

Cummings a Murray (1987) testovali 70 učitel'ov (35 mužov), priemerný vek 37 rokov, prax v školstve medzi 1 a 25 rokov. Split-half reliabilita testu bola dostačujúca, autori uzatvárajú, že test je možné použit' na dospelú populáciu spolu s pôvodnými normami. Výsledky ukázali, že nie sú nutné oddelené normy pre mužov a ženy, medzi pohlaviami nebol signifikantný rozdiel. Autori teda navrhujú spojenie noriem pre oba pohlavia (Jackson, Messick \& Myers, 1964; Cummings \& Murray, 1987).

Hao a kolegovia (2013) taktiež nezistili rozdiely medzi pohlaviami na vzorku 286 zdravých pravákov a praváčok testovaných EFT a zobrazovacími metódami mozgu, pričom hlavným prínosom štúdie bol silný vzt’ah medzi výsledkami v EFT a šedou hmotou v parietálnom laloku, kde sa podl'a autorov nachádza centrum spracovania priestorovej informácie (Hao et al., 2013). 
Lis and Powers (1979) testovali 22 detí pomocou GEFT, následne po dvoch týždňoch pomocou prenosného RFT a po d'alších dvoch týždňoch znova pomocou GEFT. Výsledky oboch testov signifikantne navzájom korelovali, čo je v rozpore s výsledkami Bergmana a Engelbrektsona (1973), ktorý odhalili len malé spoločné percento rozptylu medzi EFT a RFT. Vo svojej štúdii testovali participantov pomocou EFT, RFT a d'alšími testami, aby následne pomocou faktorovej analýzy odhalili, aké faktory sýtia použité testy. Ich výsledky ukázali, že RFT meria špecifický faktor, ktorý je úzko spojený so schopnost’ou odhadovat' skutočnú vertikálnu pozíciu. Najprekvapivejšie je ale zistenie, že výsledky EFT a RFT mali spoločných len 4-16 \% rozptylu a zároveň sýtia iné faktory. Z toho vyplýva, že RFT a EFT pravdepodobne nie sú ekvivalentné metódy na meranie závislosti/nezávislosti na poli. Autormi získané výsledky prinášajú otázky o validite metód a o faktoroch na pozadí tohto kognitívneho štýlu (Bergman \& Engelbrektson, 1973). V ich prípade ale šlo o EFT administrovaný jednotlivo, v prípade Lis a Powersa (1979) išlo o skupinovú formu testu. V ich obsahu ale nie je zásadný rozdiel, je teda zaujímavé, že autori dospeli k odlišným výsledkom.. Lis a Powers (1979) zároveň nenašli významné rozdiely medzi chlapcami a dievčatami, takže tak ako v predošlých prípadoch navrhujú spoločné normy (Lis \& Powers, 1979).

\section{Kritika závislosti a nezávislosti na poli ako kognitívneho štýlu}

Kritika Witkinovho konceptu závislosti a nezávislosti na poli sa začala objavovat' v 80. rokoch. Jej hlavným argumentom boli výsledky niekol'kých štúdií, ktoré naznačovali, že jedinci nezávislí na poli dosahujú signifikantne lepších výsledkov vo väčšine úloh zameraných na kognitívne schopnosti. Tento fakt naznačuje, že závislost' a nezávislost' na poli nie je v skutočnosti kognitívny štýl, ale kognitívna schopnost'. Pre vysvetlenie, kognitívny štýl z podstaty svojej definície predstavuje dimenziu s dvoma (alebo viacerými) pólmi, ktoré sú si rovné. Kognitívne štýly predstavujú rozdielne tendencie v spracovaní informácií a celkovo v správaní, ale ani jeden z pólov určitého kognitívneho štýlu by nemal byt' pre jedinca výhodnejší ako ten druhý. Kognitívna schopnost' naopak predstavuje určitú vlastnost', ktorej vyššia miera je považovaná za výhodu (napr. inteligencia; Khatip \& Hosseinpur, 2011). Autori Miyake, Witzki a Emerson (2001) zastávajú podobný názor a závislost'/nezávislost' na poli sa podl'a nich prekrýva s určitými štruktúrami pracovnej pamäte. Autori použili dual - task paradigma, kedy participanti plnili dve úlohy zároveň, pričom sa sledoval vplyv jednej úlohy na druhú. Výsledky ukázali, že úlohy, ktoré vyžadujú zapojenie centrálnej exekutívy a vizuospaciálneho náčrtníka signifikantne negatívne ovplyvnili výkon participantov v Hidden Figures Test (test vel'mi podobný Witkinovmu pôvodnému EFT). Záverom teda bolo, že výkon v úlohách ako Hidden Figures Test a jemu podobných sú silne ovplyvnené kapacitou pracovnej pamäte, z čoho autori vyvodzujú, že Witkinov koncept závislosti a nezávislosti na poli je v skutočnosti kognitívna schopnost' úzko spojená s kapacitou pracovnej pamäte (Miyake et. al, 2001; Rittschof, 2010). 
MacLeod, Jackson a Palmer (1986) vo svojom článku hypotetizujú, že nezávislost’ na poli je v skutočnosti priestorová kognitívna schopnost'. Autori otestovali 60 študentov (30 mužov) použitím RFT, GEFT ako testov závislosti/nezávislosti na poli a testami priestorovej schopnosti, konkrétne Spatial Relations subtestom z Multiple Aptitude Test a Blocks Design subtestom z WAIS. Ako kontrolná úloha bol zvolený test verbálnych schopností (Lorge - Thomdike Verbal Battery). Výsledky ukázali silnú koreláciu medzi výkonom participantov v priestorových úlohách a nezávislost'ou na poli. Korelácia medzi verbálnou úlohou a závislost'ou/nezávislost'ou na poli sa nepreukázala. Faktorová analýza zároveň nepotvrdila, že nezávislost' na poli a priestorová kognitívna schopnost' by boli dva oddelené konštrukty. Autori teda na záver vyjadrujú myšlienku, že nezávislost' na poli je v skutočnosti totožná s priestorovou kognitívnou schopnost'ou (MacLeod et al., 1986).

Mnoho d'alších autorov predpokladá, že nezávislost' na poli je kognitívna schopnost' (Guisande et al., 2007; Khatib \& Hosseinpur, 2011; Tinajero \& Páramo, 1997; Zhang, 2004). Zhang (2004) našiel koreláciu medzi výkonom v EFT a celkovým výkonom v kurze geometrie medzi univerzitnými študentami. Tinajero a Páramo (1997) testovali deti vo veku 13-16 rokov pomocou GEFT a porovnávali ich výkon v teste s celkovým akademickým výkonom v 6 školských predmetoch. Našli pozitívnu koreláciu medzi vyššou mierou nezávislosti na poli a akademickými výsledkami vo všetkých predmetoch.

„Odvtedy ako bolo zistené, že subjekty nezávislé na poli vykazujú lepší výkon ako subjekty závislé na poli v určitých intelektuálnych úlohách, psychológovia začali spochybňovat' predpokladanú neutralitu závislosti a nezávislosti na poli navrhujúc, že tento kognitívny štýl nie je v podstate nič viac než alternatívny spôsob nazerania na úroveň schopnosti. “(vol’ne preložené z Tinajero a Páramo 1997, s. 201)

Guisande a kolegovia (2007) sa vo svojej štúdii zamerali na pozornostné úlohy. Otestovali 149 detí pomocou detského EFT a rôznych pozornostných úloh a zistili, že vo všetkých pozornostných úlohách skórovali výrazne lepšie deti s vyššou mierou nezávislosti na poli podl'a detského EFT. Autori uzatvárajú, že dôvodom slabšieho výkonu participantov závislých na poli (či s vyššou mierou závislosti na poli) v množstve rôznych kognitívnych úlohách môže byt' nedostatočná schopnost' zamerat' pozornost' na plnenú úlohu. S tým úzko súvisia výsledky článku z roku 1965 Fitzgibbonsa a kolegov, ktorých zámerom bolo popísat', ako sa líšia participanti závislí a nezávislí na poli v úlohách nezámerného učenia (incidental learning). Participantky boli testované pomocou Digit symbol subtestu z WAIS a zároveň boli vystavené interferujúcej úlohe, kedy im bolo povedané, že v plachtou oddelenej časti miestnosti prebieha iný výskum. Následne boli testované, do akej miery si pamätajú informácie z interferujúcej úlohy (išlo o prehrávanie slov z magnetofónovej pásky). Participantky závislé na poli si pamätali signifikantne viac slov s emočným, či sociálnym nábojom, ako participantky nezávislé na poli. Podobne si pamätali viac o examinátorovi, ako o neutrálnych charakteristikách miestnosti, kde boli testované. Tento efekt sa objavil iba u participantiek závislých na poli. Čo je ale zaujímavé, participantky závislé na poli mali výrazne horšie výsledky v Digit symbol teste, teda vo fokálnej úlohe, 
ako participantky nezávislé na poli. Z toho autori vyvodzujú, že závislost' na poli je spojené $\mathrm{s}$ lepším výkonom $\mathrm{v}$ testoch nezámerného/náhodného učenia sociálne relevantného materiál, zatial' čo nezávislost' na poli sa viaže s lepším výkonom vo fokálnej úlohe (Fitzgibbons et al., 1965). Tieto zistenia naznačujú, že závislost' na poli sa môže skutočne vyznačovat' zhoršeným sústredením participantov na fokálnu úlohu, čo znižuje ich výkon (Guisande et al., 2007; Fitzgibbons et al., 1965). Autori uzatvárajú svoju štúdiu tvrdením, že nezávislost' na poli sa vyznačuje prístupom orientovaným na úlohu a výkon, závislost' na poli naopak orientáciou na sociálne prostredie (Fitzgibbons et al., 1965).

Goldstein a Chance (1965) testovali stálost' výkonu v EFT a zistili, že tréning výrazne zlepšuje výkon, zároveň tiež zmenšuje rozdiely medzi pohlaviami vo výsledkoch v tomto teste. Autori teda prichádzajú s kritikou, ktorá je postavená na ich výsledkoch a vychádza z predpokladu, že kognitívne štýly sú stále a nepodliehajú tréningu (Witkin et al., 1954 in Goldstein \& Chance, 1965). V prípade EFT a závislosti na poli je pomocou tréningu možné zvýšit' výkon participanta pôvodne závislého na poli na úroveň výkonu participantov nezávislých na poli. Tento záver teda spochybňuje závislost' na poli ako kognitívne štýl. K podobným výsledkom dospeli i Ludwig a Lachnit (2004), ktorí vo svojom experimente testovali participantov počas troch sedení oddelených siedmimi dňami vždy s použitím úloh z predošlého sedenia spolu s novými úlohami. Jednalo sa opät' o vyhl'adávanie jednoduchého figúry v komplexnom dizajne (teste zodpovedá svojím obsahom EFT). Výsledky ukázali zvyšujúcu sa správnost’ a rýchlost' odpovedí naprieč sedeniami, no prekvapivo nie len u známych úloh, ktoré participant riešil už v predošlom sedení. Tento efekt sa objavil i u nových úloh, autori teda predpokladajú vplyv tréningu na výsledky v nových úlohách (Ludwig \& Lachnit, 2004). Autori vysvetl'ujú výsledky pomocou transferu figurálneho aspektu, obsahujúceho detaily a elementy figúr vyhl'adávané vkomplexných dizajnoch, alebo pomocou procedurálneho aspektu, teda zlepšením stratégií hl'adania, celkového oboznámenia sa s úlohou a zvolením správneho prístupu ku každej úlohe. Oba tieto aspekty boli prenesené zo známych úloh na tie nové, a tým sa zvýšila správnost’ a rýchlost’ odpovedí. Autori na záver vyjadrujú názor, že percepčné úlohy tohto typu podliehajú transferu a tréning má na výkon určitý vplyv, čo sa nezhoduje s pôvodným Witkinovým názorom o kognitívnych štýloch nepodliehajúcim tréning (Ludwig \& Lachnit, 2004; Witkin et al., 1954 in Goldstein \& Chance, 1965).

\section{GEFT a súčasnost'}

Obdobie kritiky konceptu závislosti a nezávislosti na poli ako kognitívneho štýlu prinieslo isté pochybnosti o tom, či má d'alej zmysel sa týmto konceptom a teda i testom, ktorý ho údajne meria, zaoberat'. Na jednej strane je stále pomerne nejasné, či test GEFT meria skutočne kognitívny štýl tak, ako to zamýšl’al Witkin, no na strane druhej je to test, ktorý môže priniest' do diagnostiky kognitívnych schopností staronový element. Z pohl'adu kritikov konceptu kognitívneho štýlu závislosti a nezávislosti na poli test však predstavuje zaujímavý diagnostický nástoj, ktorý môže po jeho revidovaní a vytvorení nových noriem poslúžit' inému účelu, než na aký bol vytvorený. McLeod et al., (1986) 
ukazujú, že test by potenciálne mohol slúžit' k meraniu priestorovej kognitívnej schopnosti, Tinajero a Páramo (1997) zase uvažujú nad všeobecnou inteligenciu, test by teda mohol by súčast’ou inteligenčných testov. Tieto úvahy by však vyžadovali d'alšie skúmanie, najmä vytvorenie nových noriem a overenie psychometrických vlastností testu. Osobne považujem test za zaujímavý artefakt, ktorý ale ako je zrejmé z citovanej literatúry, predstavuje v súčasnosti viac historickú kuriozitu, než využívaný nástroj. (V blízkej minulosti sa testom aktívne zaoberal napríklad doktor Humpolíček z brnenskej katedry psychológie pri Filozofickej fakulte Masarykovej univerzity, ktorý téme venoval svoju diplomovú i rigoróznu prácu (Humpolíček, 2001a; 2001b). V spomínaných publikáciách sa testu venuje z tradičného uhla pohl'adu a báda nad jeho prepojením s osobnost'ou.) Podl'a môjho názoru je v teste GEFT skrytý nevyužitý diagnostický potenciál. Vo svojej práci (Krajčíková, 2014) ukazujem, že test podobný GEFT vykazuje určitý vzt'ah stestom mentálnych rotácií, ktorý je používaný práve kskúmaniu abstraktného priestorového myslenia. Bohužial test GEFT je v českom diagnostickom kontexte vel'mi náročné získat' a normy sú pomerne zastarané. Preto sme v práci (2014) použili figúry zostavené na základe pôvodného Witkinovho testu a nepoužili sme normy ako také, ale sledovali sme reakčné časy subjektov spolu s počtom správne vyriešených úloh. Ked’že sme vychádzali s predpokladu, že test meria priestorovú schopnost', reakčné časy predstavovali dobrý nástroj mierky tejto schopnosti. Toto použitie či už testu pôvodného, alebo testu zostaveného na jeho základe, by mohlo do budúcna predstavovat' zaujímavú formu testovania abstraktného priestorového myslenia a priestorovej kognitívnej schopnosti (napríklad pri prijímacích skúškach na vysoké školy, pri testoch študijných predpokladov a pod.).

\section{Záver}

Ako vyplýva z vyššie popísaného, nie je vôbec jednoduché povedat', čo EFT vlastne meria. Z kapitoly o jeho normách a psychometrických vlastnostiach vyvstáva otázka, či sú normy aktuálne, či ich je možné zlúčit' pre mužov i ženy, alebo sú ženy skutočne častejšie závislé na poli, tak ako to vyšlo Witkinovi pri jeho bádaní, či skupinová administrácia testu je porovnatel'ná s administráciou individuálnou, a či jeho skrátená verzia má skutočne dostačujúce psychometrické parametre k získaniu výsledkov porovnatel'ných s verziou kompletnou. Test sám o sebe je kontroverzný, no jeho úplné zavrhnutie je predčasné. Ako hovorí MacLeod et al., (1986), test by mohol slúžit' na testovanie priestorovej kognitívnej schopnosti. Bolo by však potreba toto jeho využitie hlbšie preskúmat' a overit'. Momentálne je test využívaný v školskej psychológii a vo výskume, no v budúcnosti by mohol poslúžit’ úplne iným účelom na aké test Witkin pôvodne zostavil. 


\section{Zoznam zdrojov}

Bergman, H., \& Engelbrektson, K. (1973). An exaination of faktor structure of Rod-and-Frame test and Embedded Figures Test. Perceptual and Mottor Skills, 37, 939-947.

Cummings, A.L., \& Murray, H.G. (1987). Psychometric data on the Group Embedded figures test for a sample of adult learners. Perceptual and Motor Skills, 65, 583-586.

Čeněk, J. (2016). Interkulturní rozdíly ve zrakovém vnímání. (Doctoral Dissertation). Brno: Filozofická fakulta Masarykovy univerzity. Retrieved from: https://is.muni.cz/vyhledavani/.

Fitzgibbons, D., Goldberger, L., \& Eagle, M. (1965).Field dependence and memory for incidental material. Perceptual and Motor Skills, 21, 743-749.

Goldstein, A.G., \& Chance, J.E. (1965). Effect of practice on sex-related differences in performance on Embedded Figures. Psychon. Sci., 3, 361-362.

Guisande, M.A., Páramo, M.F., Tinajero, C., \& Almeida L.S. (2007). Field dependenc independence (FDI) cognitive style: An analysis of attentional functioning. Psicothema, 19(4), 572-577.

Goodenough D.R. (1976). The role of individual differences in field dependence as a factor in learning and memory. Psychological Bulletin, 83(4), 675-694.

Hao, X., Wang, K., Li, W., Yang, W., Wei, D., Qiu, J., \& Zhang, Q. (2013). Individual differences in brain structure and resting brain function underlie cognitive styles: Evidence from the Embedded Figures Test. PLoS ONE, 8(12), 1-9.

Humpolíček, P. (2001a.) Závislost na poli (Field In/Dependency). Uvedení do české psychodiagnostiky. (Diploma thesis). Brno: Filozofická fakulta Masarykovy univerzity.

Humpolíček, P. (2001b). Závislost na poli - osobnost. (Dissertation). Brno: Filozofická fakulta Masarykovy univerzity, 2001b. 105 s.

Jackson, D.N. (1956). A short form of Witkin's Embedded-Figures Test. Journal of abnormal and social psychology, 53, 254-255.

Jackson, D.N., Messick, S., \& Myers, C.T. (1964). Evaluation of group and individual forms of embedded figures measures of field-independence. Educational and Psychological Measurement, 24, 177-192.

Khatip, M., \& Hosseinpur, R.M. (2011). On the validity of the Group Embedded Figures Test (GEFT). Journal of Language Teaching and Research, 2(3), 640-648).

Kozhevnikov, M. (2007). Cognitive styles in the context of modern psychology: Toward an integrated framework of cognitive style. Psychological bulletin, 133(3), 464-481.

Krajčíková, L. (2014). Field independence as a spatial cognitive ability: Correlation study of verbal and spatial short term memory. (Diploma Thesis). Retrieved from: https://is.muni.cz/vyhledavani/.

Lis, D.J., \& Powers, J.E. (1979). Reliability and validity of the Group Embedded figures test for a grade school sample. Perceptual and Motor Skills, 48, 660-662.

Ludwig, I., \& Lachnit, H. (2004). Effects of practice and transfer in the detection of embedded figures. Psychological Research, 68, 277-288. 
MacLeod, C.M., Jackson, R.A. \& Palmer J. (1986). On the relation between spatial ability and field dependence. Intelligence, 10, 141-151.

Miyake, A., Witzki, A.H., \& Emerson, M.J. (2001). Field dependence-independence from a working memory perspective: A dual-task investigation of the Hidden Figures Test. Memory, $9(4 / 5 / 6), 445-457$.

Poirel, N., Pineau, A., Jobard, G., \& Mellet, E. (2008). Seeing the forest before the trees depends on individual field-dependency characteristics. Experimental Psychology, 55(5), 328-333.

Rittschof, K.A. (2010). Field dependence-independence as visuospatial and executive functioning in working memory: implications for instructional systems design and research. Educational Technology Research and Development, 58(1), 99-114.

Svoboda, M. (2010). Psychologická diagnostika dospělých. Praha: Portál. ISBN: 978-80-262-03636, s. 488.

Tinajero, C., \& Páramo, M.F. (1997). Field dependence-independence and academic achievement: a re-examination of their relationship. British Journal of Educational Psychology, 67, 199212.

Wagemans, J., Elder, J. H., Kubovy, M., Palmer, S. E., Peterson, M. A., Singh, M., \& von der Heydt, R. (2012). A century of gestalt psychology in visual perception: I. Perceptual grouping and figure-ground organization. Psychological Bulletin. 138(6), 1172-1217.

Witkin, H.A. (1950). Individual differences in ease of perception of embedded figures. Journal of Personality, 19(1), 1-15.

Witkin, H.A. (1965). Psychological differentiation and forms of pathology. Journal of Abnormal Psychology, 70(5), 317-336.

Witkin, H.A., Goodenough, D.R., \& Oltman, P.K. (1979). Psychological differentiation: Current status. Journal of Personality and Social Psychology, 37(7), 1127-1145.

Zhang, L., (2004). Field-dependence/independence: cognitive style or perceptual ability?validating against thinking styles and academic achievement. Personality and Individual Differences, 37, 1295-1311. 


\section{Lenka Krajčíková (2017): Field (in)dependence: cognitive style or ability?}

Presented short paper deals with testing of cognitive style of field dependence/independence by Herman Witkin. This cognitive style described in fifties was wildly criticized in last couple of decades. The criticism was aimed towards the definition of a cognitive style and also towards methods evaluating and testing this so called cognitive style. The paper describes various methods of testing this style and provides brief overview of a criticism of the concept. The main goal of this paper is to provide a historical overview of testing cognitive style of field dependence/independence and to evaluate test created for that purpose (Embedded Figures Test). The reader will find out that EFT is not a completely valid method of testing cognitive style mentioned above and there are some doubts about what this test is really measuring. EFT will be introduced from a slightly different angle, as an interesting method of testing spatial cognitive ability or general intelligence, but these new options of use of EFT require further research.

Key words: field dependence, cognitive style, cognitive ability, psychometrics 